\title{
Operational Audit of Accounts Receivable (Study at PT. Sanserita Jaya)
}

\author{
Ahmad Winanto ${ }^{a, 1, *}$, Fika Aryani ${ }^{b, 2}$ \\ a Politeknik Tunas Pemuda, Tangerang, Banten 15145, Indonesia \\ b Institut Ilmu Sosial dan Manajemen STIAMI,Jakarta Pusat, DKI Jakarta 10530, Indonesia \\ 1 ahmadwinanto85@gmail.com *; 2 aryanifika@gmail.com \\ * corresponding author
}

ARTICLE INFO

\section{Article history}

Received

Revised

Accepted

Keywords

Operational Audit;

Accounts receivable;

Effective

\begin{abstract}
An operational audit of accounts receivable is needed because it plays a role in assessing the effectiveness of accounts receivable so that it runs according to established procedures and policies. This study aims to determine the role of operational audits on the functions of accounts receivable and to determine the function of accounts receivable in overcoming the accounts receivable turnover. The research was conducted at PT. Sanserita Jaya which is a company engaged in the distribution of raw materials and printing machinery. The method used in this research is descriptive research method. The focus in this research is the procedure for the function of the accounts receivable section. The results of the study explained that based on data analysis in 2017-2019, showed that the procedure of accounts receivable was quite effective but there were still many weaknesses found, based on these weaknesses the researchers submitted several recommendations for improvements so that the company could fix existing weaknesses and increase the effectiveness of managing its accounts receivable.
\end{abstract}

\section{PENDAHULUAN}

Salah satu tolak ukur keberhasilan perusahaan adalah dilihat dari kegiatan penjualannya. Semakin tinggi tingkat penjualan maka akan menghasilkan laba yang diinginkan sehingga dapat meningkatkan kinerja perusahaan, mempertahankan posisi bisnis dan untuk mencapai tujuan perusahaan serta berdaya saing dalam dunia usaha. Dalam melaksanakan kegiatan penjualan ini terbagi menjadi dua sistem yaitu sistem penjualan tunai dan sistem penjualan kredit. Penjualan kredit menjadi daya tarik tersendiri bagi konsumen karena dengan adanya termin pembayaran pada tagihan tersebut, barang yang dibeli dapat dibawa dan digunakan langsung. Disatu sisi penjualan kredit akan menimbulkan piutang usaha bagi perusahaan. Penjualan dan piutang usaha ini harus mendapatkan perhatian yang khusus oleh perusahaan agar berjalan sesuai dengan standar operasional perusahaan dan menghindari adanya kecurangan(fraud), human error, dan gagal bayar (bad debt) maka dibutuhkanlah audit operasional atas piutang usaha agar berjalan sesuai standar yang telah diterapkan perusahaan. Audit operasional atas piutang usaha sangat diperlukan karena berperan menilai efektivitas piutang usaha yang nantinya akan menghasilkan output yaitu berupa rekomendasi kepada manajemen perusahaan untuk dilakukan perbaikan demi kemajuan perusahaan.

Penelitian yang dilakukan oleh Tebety et al. (2013) pada PG. Meritjan mengenai penerapan audit operasional pada bagian produksi menunjukkan hasil bahwa penerapan audit operasional pada bagian produksi tahun 2010-2011 sudah efisien dan efektif dalam hal penggunaan bahan baku, tenaga kerja dan penggunaan kapasitas mesin. Berbeda dengan penelitian yang dilakukan oleh Satsangkaryon (2015) pada PT. Binakarsa Swadaya bahwa peningkatan nilai audit operasional atas piutang usaha yang tidak diikuti dengan meminimalkan piutang tak tertagih. Menurut Tebety et al. (2013), hasil audit operasional menyajikan informasi tentang hasil analisa serta penilaian mengenai kegiatan perusahaan sehingga perusahaan dapat mendapatkan informasi yang berguna dan dapat mengetahui kelemahan yang terjadi dalam operasional perusahaannya sehingga dapat meningkatkan pengendaliannya. Penelitian selanjutnya mengenai penerapan audit operasional dilakukan oleh Bela et al.(2016) untuk mengevaluasi kelemahan kegiatan penjualan yang telah berjalan kemudian dianalisa selanjutnya dan diberikan rekomendasi perbaikan atas kelemahan yang 
ditemukan dalam kegiatan penjualan agar tidak merugikan perusahaan sehingga tujuan perusahaan dapat tercapai.

Berdasarkan uraian diatas mengenai audit operasional, maka diambil penelitian serupa tentang audit operasional namun fokus pada fungsi piutang usaha PT. Sanserita Jaya. PT Sanserita Jaya merupakan perusahaan yang bergerak di bidang penyedia bahan baku dan mesin-mesin finishing untuk Percetakan dan Penerbit di Indonesia, serta menjual kawat spiral, board, covering material untuk kalender meja, kertas fancy untuk digital printing, bahan-bahan Polyutherane leather untuk cover agenda, dll. Perusahaan tersebut sudah memasok bahan baku untuk beberapa perusahaan besar dan perbankan seperti Bank BRI, Bank BNI, Bank Mandiri, dll. Alasan peneliti ingin mengevaluasi fungsi piutang yang telah berjalan dalam PT. Sanserita Jaya karena perusahaan tersebut lebih banyak transaksi penjualan kredit sehingga jumlah piutang usaha yang dimiliki juga besar, dan piutang usaha merupakan asset yang cukup material. Oleh karena itu dibutuhkan manajemen pengelolaan piutang yang baik agar jumlah asset yang terdapat dalam piutang usaha tidak mengganggu aliran kas perusahaan.

Pengelolaan piutang PT. Sanserita Jaya dinilai belum cukup efektif hal ini dapat dilihat dari data jumlah piutang usaha dari tahun 2017 sampai dengan 2019 selalu meningkat. Pada akhir tahun 2017 jumlah piutang usaha PT. Sanserita Jaya sebesar Rp. 13.355.411.423 menjadi Rp. 14.420.590.818 pada akhir tahun 2018 atau meningkat $7.98 \%$, serta pada akhir tahun 2019 jumlah piutang usaha sebesar Rp. 17.253.587.695 atau meningkat $19.65 \%$ dari jumlah piutang usaha tahun sebelumnya. Oleh karena itu peneliti ingin mengevaluasi apakah fungsi piutang usaha sudah berjalan dengan baik, efektif dan efisien dan mengidientifikasi kelemahankelemahan yang ada dalam fungsi piutang usaha PT. Sanserita Jaya sehingga dapat diperbaiki agar tujuan perusahaan dapat tercapai.

Sehubungan dengan pengelolaan piutang yang baik, Mbula et al. (2016) melakukan penelitian pada perusahaan modal ventura atas pengaruh manajemen piutang terhadap kinerja keuangan perusahaan menunjukkan adanya hubungan positif antara piutang dan kinerja perusahaan, piutang usaha menjelaskan $25,7 \%$ dari kinerja keuangan sementara variasi $74,3 \%$ djelaskan oleh faktor-faktor lain. Penelitian yang dilakukan Mbula et al.(2016) merekomendasikan perusahaan menerapkan kebijakan kredit yang baik untuk meningkatkan manajemen piutang yang efisien sehingga dapat meningkatkan kinerja keuangannya. Tahumang et al.(2017) menyatakan bahwa sistem pengendalian internal piutang yang jelas saling berkaitan dengan proses terjadinya pertumbuhan piutang. Berbeda dengan penelitian Duru et al. (2014) pada perusahaan manufaktur makanan dan minuman di Nigeria, bahwa piutang memiliki hubungan negatif dan tidak signifikan dengan profitabilitas atau dapat diartikan manajemen piutang tidak berpengaruh pada besar kecilnya profitabilitas sebuah perusahaan. Berdasarkan penelitian Mbula et al (2016) dan Tahumang et al.(2017) mengenai manajemen piutang dan sistem pengendalian internal piutang usaha menjelaskan betapa pentingnya piutang usaha sebagai asset yang cukup material bagi perusahaan.

Penelitian ini mengacu pada penelitian yang dilakukan oleh Tebety et al. (2013) dan Satsangkaryon (2015) sehingga memberikan inspirasi bagi peneliti untuk melakukan penelitian mengenai peranan audit operasional atas piutang usaha pada PT. Sanserita Jaya periode tahun 2017 sampai dengan tahun 2019. Yang membedakan penelitian ini dengan penelitian yang dilakukan oleh Tebety et al. (2013) adalah audit operasional yang dilakukan dalam penelitian ini adalah pada fungsi piutang usaha bukan pada bagian produksi dan juga perbedaan bidang perusahaan dimana PT. Sanserita Jaya sebagai perusahaan distributor bukan perusahaan manufaktur. Sedangkan dengan penelitian Satsangkaryon (2015) yang membedakan adalah dalam peneltian ini fokus pada proses tahapan audit operasional pada piutang usaha. Data Penelitian yang diambil oleh peneliti adalah dari tahun 2017 sampai dengan tahun 2019. Penelitian ini bertujuan untuk mengetahui penerapan audit operasional pada fungsi piutang usaha pada PT. Sanserita Jaya dan untuk mengevaluasi kelemahan-kelamahan yang terjadi atas fungsi piutang usaha.

\section{STUDI PUSTAKA}

\section{Auditing}

Menurut Sukrisno Agoes (2012:4) Auditing adalah suatu pemeriksaan yang dilakukan secara sistematis oleh pihak yang independen terhadap laporan keuangan yang telah disusun oleh manajemen beserta catatancatatan pembukuan dan bukti-bukti pendukungnya dengan tujuuan untuk memberikan pendapat mengenai kewajaran laporan keuanagan tersebut. Menurut Arens (2012:15), Auditing adalah pengumpulan serta 
pengevaluasian bukti-bukti atas informasi untuk menentukan dan melaporkan tingkat kesesuaian informasi tersebut dengan kriteria-kriteria yang ditetapkan.

\section{Audit Operasional}

Audit operasional menurut Sukrisno Agoes (2012:11-13) adalah suatu pemeriksaan terhadap kegiatan operasi suatu perusahaan, termasuk kebijakan akuntansi dan kebijakan operasional yang telah ditentukan oleh manajemen, untuk mengetahui apakah kegiatan operasi tersebut sudah dilakukan secara efektif, efisien dan ekonomis. Yang ditekankan adalah untuk mencapai efektivitas, efisiensi dan ekonomisasi dalam usaha. Tujuan dari audit operasional adalah untuk menilai kinerja, mengidentifikasi bidang-bidang yang memerlukan perbaikan dan memberikan rekomendasi. Menurut Turetken et al. (2019) melakukan pemeriksaan internal menjadi salah satu praktik utama bagi sebuah organisasi atau perusahaan untuk mengendalikan kepatuhan terhadap prosedur, standar dan kebijakan yang telah ditetapkan.

\section{Tahapan Audit Operasional}

Menurut Bhayangkara (2015:15), ada beberapa tahapan yang harus dilakukan dalam audit operasional yaitu :

a. Audit pendahuluan (Preliminary Survey) dilakukan untuk mendapatkan informasi latar belakang terhadap objek yang diaudit dengan penelaahan terhadap berbagai peraturan dan kebijakan tertentu yang berkaitan dengan aktivitas yang diaudit, serta menganalisis informasi-informasi yang telah diperoleh untuk mengidentifikasi temuan potensial yang mengandung kelemahan pada perusahaan yang diaudit.

b. Penelaahan dan pengujian atas sistem pengendalian manajemen (Review and Testing of Management Control System) dilakukan untuk mengevaluasi dan menguji efektivitas dari pengendalian manajemen yang terdapat di perusahaan dalam mendukung pencapaian tujuan perusahaan.

c. Pengujian terinci (Detail Examination) dilakukan untuk memeriksa terhadap transaksi perusahaan apakah prosesnya sesuai dengan kebijakan yang telah ditetapkan perusahaan. Auditor mengumpulkan bukti yang kompeten untuk mendukung tujuan audit yang telah ditentukan dan mengembangkan bukti temuan untuk mencari keterkaitan dengan temuan lainnya dalam menguji permasalahan yang berkaitan dengan tujuan audit.

d. Pengembangan laporan (Report Development) memberikan laporan yang diberikan kepada manajemen perusahaan berisi temuan pemeriksaan mengenai penyimpangan yang terjadi sehingga menimbulkan inefisiensi, inefektivitas dan pemborosan serta kelemahan dalam sistem pengendalian manajemen yang terdapat di dalam perusahaan. Selain itu auditor memberikan rekomendasi atau saran-saran perbaikan dalam mendukung pencapaian tujuan perusahaan.

e. Implementasi tindak lanjut atas rekomendasi yang diberikan auditor merupakan bentuk komitmen manajemen perusahaan dalam meningkatkan kinerja perusahaan atas beberapa kelemahan atau kekurangan yang masih terjadi. Melaksanakan tindak lanjut sesuai dengan rekomendasi yang diberikan guna perbaikan tindakan untuk tujuan perusahaan di masa yang akan datang.

\section{Piutang Usaha}

Menurut Kieso (2015:36) piutang adalah jumlah yang terhutang oleh pelanggan untuk barang dan jasa yang telah diberikan sebagai bagian dari operasi bisnis normal. Dan menurut Gade (2010:35) piutang adalah merupakan tagihan perusahaan terhadap badan/seseorang akibat adanya penjualan barang/jasa dengan cara kredit. Sementara menurut Warren et al (2015:448) piutang mencakup seluruh uang yang diklaim terhadap entitas lain, termasuk perorangan, perusahaan, dan organisasi lain. Berdasarkan penelitian yang dilakukan oleh Shi et al. (2016) faktor penentu piutang usaha di perusahaan ditentukan oleh kelayakan kredit suatu perusahaan, ukuran perusahaan, usia perusahaan, kualitas produk dan kemampuan pembiayaan internal, serta diskriminasi harga.

Berikut ini ada beberapa ciri internal kontrol yang baik atas piutang usaha :

a. Adanya pemisahan tugas dan tanggung jawab antar yang melakukan penjualan, mengirimkan barang, melakukan penagihan, memberikan otorisasi atas penjualan kredit, membuat faktur penjualan dan melakukan pencatatan.

b. Digunakan formulir-formulir yang bernomor urut tercetak (prenumbered).

Ahmad Winanto, et.al (Operational Audit of Accounts Receivable (Study at PT. Sanserita Jaya)...) 
c. Diadakannya sub buku besar piutang atau kartu piutang (accounts receivable subledger card) untuk masing-masing pelanggan yang selalu di update (dimutakhirkan).

d. Setiap akhir bulan dibuat aging schedule piutang (analisa umur piutang ).

e. Setiap akhir bulan jumlah saldo piutang dari masing-masing pelanggan dibandingkan (direconcile) dengan jumlah saldo piutang buku besar.

f. Mutasi kredit diperkirakan piutang (buku besar dan sub buku besar) yang berasal dari retur penjualan dan penghapusan piutang harus diotorisasi oleh pejabat perusahaan yang berwenang.

Pada umumnya fungsi bagian piutang adalah membuat catatan piutang, menyiapkan dan mengirimkan surat pernyataan piutang, membuat daftar analisa umur piutang per periode. Dalam piutang usaha sebuah perusahaan dapat munculnya piutang tak tertagih, piutang tak tertagih ini diakibatkan dari pelanggan yang lewat membayar dari batas yang telah ditentukan dalam waktu yang lama. Besarnya piutang tak tertagih dapat dilihat dengan menghitung tingkat perputaran piutang usaha dan rata-rata pengumpulan piutang. Tingkat perputaran piutang diperoleh dengan cara membagi jumlah penjualan pada suatu periode dengan rata-rata piutang usaha periode tersebut. Sedangkan rata-rata pengumpulan piutang didapatkan dengan membagi jumlah hari dalam setahun yaitu 360 hari dengan besarnya tingkat perputaran piutang. (Satsangkaryon, 2015)

$$
\begin{aligned}
& \text { Tingkat perputaran piutang usaha }=\frac{\text { Tingkat Penjualan }}{\text { Rata-Rata Piutang Usaha }} \\
& \text { Rata-Rata Pengumpulan Piutang }=\frac{\text { Jumlah Hari Setahun (360) }}{\text { Tingkat perputaran piutang usaha }}
\end{aligned}
$$

\section{METODE PENELITIAN}

Jenis peneltian yang digunakan dalam penelitian ini adalah deskriptif. Menurut Nazir (2013:54) penelitian deskriptif merupakan suatu metode untuk meneliti kasus kelompok manusia, suatu obyek, suatu kondisi, dan suatu sistem pemikiran maupun kelas peristiwa masa sekarang. Pendekatan yang dilakukan dalam penelitian ini adalah pendekatan studi kasus dimana merupakan pengujian yang dilakukan secara rinci terhadap suatu objek penelitian.

Sumber data yang diperoleh dalam penelitian ini adalah data primer, dan dalam menganalisa data untuk penelaahan serta penilaian sistem pengendalian intern, peneliti menggunakan metode deskriptif kualitatif dengan menggunakan instrumen Internal Control Questionaires (ICQ) yaitu serangkaian pertanyaan tentang pengendalian dalam lingkup audit yang bisa digunakan untuk memahami dan mengevaluasi pengendalian intern dengan cara mengisi daftar pertanyaan yang telah disiapkan. Jawaban dapat berbentuk "Ya" yang berarti menunjukkan kekuatan internal control dan "Tidak" yang menunjukkan kelemahannya, dan "Tidak Relevan" berarti pertanyaan tersebut tidak relevan untuk perusahaan tersebut.

\section{PEMBAHASAN}

\section{Survei Pendahuluan}

Sebelum melakukan pemeriksaan terhadap suatu perusahaan auditor terlebih dahulu harus mempersiapkan audit plan (rencana pemeriksaan) yang merupakan langkah awal dan persiapan terhadap strategi secara menyeluruh terhadap tindakan-tindakan yang akan diambil dan akan dilaksanakan serta ruang lingkup pemeriksaan.

\section{Berikut ini adalah langkah-langkah audit plan PT. Sanserita Jaya :}

a. Pendalaman informasi mengenai perusahaan klien seperti kegiatan perusahaan bidang usaha dan latar belakangnya, struktur pengendalian intern klien serta sistem administrasi pembukuan.

b. Identifikasi terhadap unsur-unsur resiko pemeriksaan yang kemungkinan bisa terjadi.

c. Identifikasi tingkat kesulitan dalam pemeriksaan.

d. Mempelajari prosedur proses penjualan dan piutang usaha perusahaan.

Dalam sistem penjualan kredit, dokumen yang digunakan oleh PT. Sanserita Jaya adalah sebagai berikut : 


\section{E ISSN 2715-1212}

a. Sales Order

Sales Order adalah dokumen yang berisi order permintaan dari pelanggan yang dibuat oleh bagian sales counter dan ditandatangani oleh sales counter.

b. Delivery Order

Delivery Order adalah surat yang memberikan otorisasi kepada bagian pengiriman untuk mengirimkan barang kepada pelanggan.

c. Invoice Penjualan dan Faktur Pajak

Dokumen yang berisikan item deskripsi barang dan harga barang dan sebagai bukti bahwa barang telah diterima oleh pelanggan.

\section{d. Tanda Terima Faktur}

Tanda terima faktur adalah tanda terima yang berisikan rincian tagihan atas piutang serta tanggal jatuh tempo diberikan kepada pelanggan pada saat tukar Faktur Penjualan. Tanda terima ini digunakan untuk menagih piutang yang timbul akibat transaksi penjualan kredit kepada pelanggan.

\section{Penelaahan dan Pengujian atas Sistem Pengendalian Manajemen}

Tujuan dari tahap penelaahan dan pengujian atas sistem pengendalian manajemen adalah untuk menguji dan mengevaluasi efisiensi dan efektivitas pengendalian yang dilakukan oleh perusahaan dalam mencapai tujuan perusahaan. Jika pelaksanaan pengendalian itern perusahaan telah sesuai dengan kriteria yang ditetapkan maka dapat dikatakan pengendalian intern tersebut sangat kuat. Tetapi jika sebaliknya, maka dapat dikatakan pengendalian intern tersebut lemah.

Evaluasi pada pengendalian internal dilakukan dengan cara memberikan kuesioner pada bagian fungsi piutang usaha, kuosioner untuk pengendalian intern tersebut berdasarkan hasil jawaban dari daftar pertanyaan Internal Control Questionnaire (ICQ) atas sistem pengendalian internal PT. Sanserita Jaya pada fungsi piutang usaha, terdapat kelebihan dan kelemahan perusahaan yaitu:

Kelebihan perusahaan berdasarkan hasil ICQ adalah :

a. Penjualan yang terjadi telah dicatat dan dihitung dengan benar sesuai dengan kebijakan peraturan perusahaan dan penjualan tersebut adalah sah.

b. Seluruh invoice dan nota kredit berasal dari pengiriman dan pengembalian barang yang sah.

c. Daftar piutang usaha telah disusun dengan rinci baik nama, alamat maupun jumlah.

d. Piutang usaha yang dicantumkan adalah benar merupakan milik perusahaan.

e. Nilai piutang yang dicantumkan di dalam neraca adalah wajar dan penyajiannya dalam neraca telah diklasifikasikan dengan tepat.

Kelemahan perusahaan berdasarkan hasil ICQ adalah :

a. Bagian penjualan tidak dipisahkan dari bagian kredit.

Dengan tidak adanya pemisahan fungsi antara fungsi penjualan dan fungsi kredit maka akan berakibat pada kurang optimalnya kinerja fungsi tersebut karena masing-masing fungsi kurang terfokus dalam menjalankan fungsinya. Selain itu, dapat beresiko adanya tindak kecurangan berupa kerjasama antara bagian penjualan dengan pelanggan yang dapat merugikan perusahaan karena bagian penjualan berhubungan langsung dengan pelanggan maka bagian penjualan dapat memberikan persetujuan kredit karena memperoleh imbalan dari pelanggan.

b. Proses penagihan sering dilakukan oleh Salesman

Dalam pelaksanaan kegiatannya, salesman dapat merangkap jabatan menjadi penagih. Meskipun dalam perusahaan sudah ada fungsi debt collector. Jika salesman sedang melakukan kunjungan rutin kepada pelanggan, maka salesman ini dapat menagih piutangnya kepada pelanggan. Hal ini disebabkan menurut perusahaan akan lebih praktis. Proses penagihan yang dilakukan salesman dapat mengakibatkan salesman melakukan tindak kecurangan yang dapat merugikan perusahaan secara materiil karena tanggung jawab atas penagihan piutang tersebut menjadi terbagi antara debt collector dan sales.

Ahmad Winanto, et.al (Operational Audit of Accounts Receivable (Study at PT. Sanserita Jaya)...) 
c. Penyimpanan arsip tanda terima faktur, dimana tanda terima tersebut digunakan untuk ditagihkan kepada pelanggan kurang baik sehingga sering hilang atau tercampur dengan dokumen lainnya.

d. Pencatatan pelunasan piutang usaha atas tagihan yang sudah dibayarkan tidak update.

\section{Pengujian Terinci (Detail Examination)}

Tujuan audit dari pemeriksaan prosedur piutang usaha adalah untuk mengetahui apakah prosedur dan kebijakan atas penagihan dan pencatatan piutang usaha telah berjalan efektif dan efisien serta ketepatan pembayaran piutang usaha yang dibayarkan oleh pelanggan.

Prosedur audit yang dilakukan dalam memeriksa fungsi piutang usaha adalah :

a. Mempelajari prosedur pencatatan dan metode akuntansi yang digunakan dalam proses transaksi penjualan.

b. Memeriksa jurnal pencatatan piutang usaha.

c. Memeriksa pengiriman invoice kepada pelanggan sesuai waktu yang telah ditentukan.

d. Memeriksa pemisahan tugas antara bagian pencatatan piutang, bagian penagihan dan bagian pelunasan piutang.

e. Memeriksa umur piutang usaha dari setiap pelanggan.

f. Memberikan rekomendasi perbaikan atas kelemahan-kelemahan yang ditemui.

Berdasarkan prosedur audit yang telah dilakukan maka didapatkan hasil audit atas piutang usaha yaitu perusahaan belum memiliki pedoman tertulis mengenai pencatatan piutang usaha, proses penagihan dan pelunasan piutang usaha. Belum adanya pemisahan tugas antara salesman dengan bagian penagihan piutang serta seringkali adanya keterlambatan pengiriman invoice oleh kurir sehingga berpengaruh pada pembayaran piutang usaha yang tidak sesuai dengan term payment yang telah disepakati. Dan karena dalam proses penyimpanan file tanda terima piutang tidak tersusun dengan rapi menyebabkan sering terlewatnya penagihan kepada pelanggan yang tagihannya sudah masuk jatuh tempo.

\section{Pengembangan Laporan (Report Development)}

Pengembangan laporan (Report Development) memberikan laporan yang diberikan kepada manajemen perusahaan berisi temuan pemeriksaan atas fungsi piutang usaha, mengenai penyimpangan yang terjadi sehingga menimbulkan inefisiensi, inefektivitas dan pemborosan serta kelemahan dalam sistem pengendalian manajemen yang terdapat di dalam perusahaan. Selain itu diberikan rekomendasi atau saran-saran perbaikan dalam mendukung pencapaian tujuan perusahaan.

Tabel 1. Daftar Temuan Audit Operasional Atas Fungsi Piutang Usaha PT. Sanserita Jaya

\begin{tabular}{|l|l|}
\hline & 1) Bagian penjualan tidak dipisahkan dari bagian kredit. Terdapat perangkapan \\
& tugas antara bagian penjualan dan bagian kredit, dimana bagian penjualan \\
memberikan persetujuan kredit kepada pelanggan. & \\
2) Proses penagihan sering dilakukan oleh salesman. Dalam pelaksanaan \\
kegiatannya, salesman dapat merangkap jabatan menjadi penagih. Meskipun \\
dalam perusahaan sudah terdapat fungsi debt collector. \\
3) Perusahaan belum memiliki pedoman tertulis mengenai kebijakan dan \\
prosedur piutang usaha. \\
4) Keterlambatan pengiriman invoice oleh kurir sehingga berpengaruh pada \\
pembayaran piutang usaha yang tidak sesuai dengan term payment yang telah \\
disepakati. \\
5) Proses penyimpanan file tanda terima piutang tidak tersusun dengan rapi \\
menyebabkan sering terlewatnya penagihan kepada pelanggan yang \\
tagihannya sudah masuk jatuh tempo. \\
\hline Kriteria & 1) Fungsi penjualan harus terpisah dari fungsi kredit, jika pelanggan ingin \\
mengajukan kredit atas pembeliannya, maka fungsi penjualan adalah \\
menanyakan status kredit atau kelayakan pemberian kredit kepada bagian \\
piutang.
\end{tabular}

Ahmad Winanto, et.al (Operational Audit of Accounts Receivable (Study at PT. Sanserita Jaya)...) 


\begin{tabular}{|c|c|}
\hline & $\begin{array}{l}\text { 2) Transaksi penjualan kredit harus dilaksanakan oleh fungsi penjualan, fungsi } \\
\text { kredit, fungsi pengiriman, fungsi penagihan, dan fungsi akuntansi. Tidak ada } \\
\text { transaksi penjualan kredit yang dilaksanakan secara lengkap oleh satu fungsi } \\
\text { tersebut. } \\
\text { 3) Adanya pedoman atau kebijakan tertulis mengenai standar pengerjaan proses } \\
\text { pencatatan, penagihan dan pelunasan piutang usaha dari manajemen } \\
\text { perusahaan. } \\
\text { 4) Pengiriman tagihan kepada pelanggan dilakukan sesuai waktu yang telah } \\
\text { ditentukan oleh perusahaan atau sesuai jadwal yang diberikan oleh pelanggan. } \\
\text { 5) Penyimpanan file dokumen harus terstruktur rapi sesuai abjad nama pelanggan } \\
\text { dan rutin dalam melakukan pengecekan tagihan yang sudah jatuh tempo. }\end{array}$ \\
\hline Sebab & $\begin{array}{l}\text { 1) Perusahaan menginginkan penghematan dalam operasional penjualannya. } \\
\text { Serta perusahaan menganggap bahwa bagian penjualan lebih mengetahui } \\
\text { kondisi pelanggan, baik dari segi kelancaran pelunasan hutang dan } \\
\text { kemampuan pembayarannya. } \\
\text { 2) Menurut perusahaan akan lebih praktis jika salesman sedang melakukan } \\
\text { kunjungan rutin kepada pelanggan, maka langsung dapat menagih piutangnya } \\
\text { kepada pelanggan. } \\
\text { 3) Perusahaan hanya fokus pada target penjualan. } \\
\text { 4) Tidak ada sanksi bagi karyawan yang lalai sehingga keterlambatan atau human } \\
\text { error adalah hal yang wajar. }\end{array}$ \\
\hline Akibat & $\begin{array}{l}\text { 1) Kurang optimalnya kinerja fungsi penjualan dan fungsi kredit karena masing- } \\
\text { masing fungsi kurang terfokus dalam menjalankan fungsinya. Dan dapat } \\
\text { beresiko adanya tindak kecurangan berupa kerja sama antara bagian penjualan } \\
\text { dan pelanggan dengan memberikan persetujuan kredit karena memperoleh } \\
\text { imbalan dari pelanggan. } \\
\text { 2) Salesman dapat melakukan tindak kecurangan yang dapat merugikan } \\
\text { perusahaan secara materiil. Hal ini karena tidak adanya pemisahan tugas dan } \\
\text { banyaknya tanggungjawab yang dipegang oleh satu bagian. } \\
\text { 3) Dengan tidak adanya pedoman dan kebijakan tertulis dalam prosedur piutang } \\
\text { usaha, maka bagian piutang usaha tidak memiliki pedoman yang jelas dalam } \\
\text { menjalankan tugasnya serta bekerja sesuai pendapat mereka masing-masing. }\end{array}$ \\
\hline Rekomendasi & $\begin{array}{l}\text { 1) Perusahaan perlu membuat pemisahan fungsi yaitu antara fungsi penjualan } \\
\text { dan fungsi kredit sehingga penjualan kredit dapat lebih terkontrol dan resiko } \\
\text { piutang tak tertagih dapat dikurangi dan resiko-resiko atas tindak kecurangan } \\
\text { dapat dihindari. } \\
\text { 2) Perlu adanya kebijakan yang jelas bahwa penagihan dan tanggung jawab atas } \\
\text { hasil penagihan piutang hanya dilakukan oleh debt collector saja. } \\
\text { 3) Perusahaan perlu membuat pedoman kebijakan dan prosedur piutang usaha } \\
\text { secara tertulis untuk meningkatkan efektivitas dan efisiensi } \\
\text { 4) Perlu adanya sistem otorisasi atas terlaksananya setiap transaksi. }\end{array}$ \\
\hline
\end{tabular}

\section{Tindak Lanjut}

Implementasi tindak lanjut atas rekomendasi yang diberikan atas hasil audit operasional atas piutang usaha merupakan bentuk komitmen manajemen perusahaan dalam meningkatkan kinerja perusahaan atas beberapa kelemahan atau kekurangan yang masih terjadi. Melaksanakan tindak lanjut sesuai dengan rekomendasi yang diberikan guna perbaikan tindakan untuk tujuan perusahaan di masa yang akan datang. Berkaitan dengan fungsi bagian piutang usaha, perusahaan membuat prosedur tertulis untuk fungsi piutang usaha agar sesuai standar yang berlaku. Dan dalam hal persetujuan pemberian kredit perusahaan memberlakukan sistem otorisasi atas terlaksananya setiap transaksi yang terjadi. Sejalan dengan penelitian Tebety et al.(2013) dalam penerapan audit operasional pada bagian produksi sudah cukup baik namun masih ada ditemukan beberapa kelemahan yang kurang efisien pada tingkat produktivitas tenaga kerja sehingga diberikan rekomendasi untuk ditindaklanjuti agar dapat meningkatkan kinerja perusahaan. Dengan demikian peran audit internal dalam perusahaan sangat penting untuk mengendalikan masalah pada bagian keuangan dan bagian divisi lainnya 
yang telah ditentukan oleh manajemen untuk meningkatkan nilai perusahaan dan sesuai dengan tujuan perusahaan (Lastianti et al, 2018) .

\section{Tingkat Perputaran Piutang Usaha}

Lamanya perputaran piutang usaha dapat dilihat dengan menghitung tingkat perputaran piutang usaha dan rata-rata pengumpulan piutang. Tingkat perputaran piutang diperoleh dengan cara membagi jumlah penjualan pada suatu periode dengan rata-rata piutang usaha periode tersebut. Sedangkan rata-rata pengumpulan piutang didapatkan dengan membagi jumlah hari dalam setahun yaitu 360 hari dengan besarnya tingkat perputaran piutang.

Tabel 2. Tingkat Perputaran Piutang Usaha dan Rata-Rata Pengumpulan Piutang

\begin{tabular}{|c|c|c|c|c|}
\hline Tahun & Total Penjualan & $\begin{array}{c}\text { Rata-Rata Piutang } \\
\text { Usaha }\end{array}$ & $\begin{array}{c}\text { Tingkat } \\
\text { Perputaran } \\
\text { Piutang Usaha }\end{array}$ & $\begin{array}{c}\text { Rata-Rata } \\
\text { Pengumpulan } \\
\text { Piutang }\end{array}$ \\
\hline 2017 & Rp.31.039.235.356 & Rp.9.679.134.512 & 3,21 & 112 hari \\
\hline 2018 & Rp.31.358.230.746 & Rp.13.888.001.121 & 2,26 & 159 hari \\
\hline 2019 & Rp.41.131.255.033 & Rp.15.837.089.257 & 2,60 & 139 hari \\
\hline
\end{tabular}

a. Data diolah peneliti

Berdasarkan tabel diatas dapat dilihat tingkat perputaran piutang usaha pada tahun 2017 sebesar 3,21 dengan rata-rata pengumpulan piutang 112 hari, pada tahun 2018 tingkat perputaran piutang usaha sebesar 2,26 dengan rata-rata pengumpulan piutang sebesar 159 hari, dan pada tahun 2019 tingkat perputaran piutang usaha sebesar 2,60 dengan rata-rata pengumpulan piutang 139 hari. Idealnya untuk tingkat perputaran piutang usaha adalah 6 kali dalam setahun atau 60 hari paling lambat piutang usaha terbayarkan. Dari tabel diatas menggambarkan tingkat perputaran piutang usaha pada tahun 2017 cukup baik daripada tahun 2018 dan 2019, namun tingkat perputaran 3,21 atau 112 hari menandakan arus kas masuk dari hasil piutang usaha yang terbayarkan dari penjualan kredit sangat lama. Hal tersebut mengindikasikan peran dan fungsi bagian piutang usaha kurang efektif dan efisien dalam melakukan tugas dan tanggungjawabnya. Hasil penelitian ini sejalan dengan penelitian Satsangkaryon (2015) bahwa tingkat perputaran piutang usaha setiap tahunnya mengalami penurunan.

\section{KESIMPULAN DAN SARAN}

\section{Kesimpulan}

Penerapan audit operasional atas fungsi piutang usaha pada PT. Sanserita Jaya bertujuan untuk menilai keefektifan bagian fungsi piutang usaha yang telah berjalan selama ini. Hasil audit operasional atas fungsi piutang usaha PT. Sanserita Jaya masih ditemukan beberapa kelemahan yaitu perusahaan belum memiliki pedoman tertulis mengenai pencatatan piutang usaha, proses penagihan dan pelunasan piutang usaha. Belum adanya pemisahan tugas antara salesman dengan bagian penagihan piutang serta seringkali adanya keterlambatan pengiriman invoice oleh kurir sehingga berpengaruh pada pembayaran piutang usaha yang tidak sesuai dengan term payment yang telah disepakati. Dan karena dalam proses penyimpanan file tanda terima piutang tidak tersusun dengan rapi menyebabkan sering terlewatnya penagihan kepada pelanggan yang tagihannya sudah masuk jatuh tempo.

Selain itu lamanya perputaran piutang usaha PT. Sanserita Jaya dapat dilihat dari tingkat perputaran piutang usaha. Peneliti mengambil data selama 3 (tiga) tahun yaitu dari tahun 2017 sampai dengan tahun 2019 diperoleh hasil bahwa tingkat perputaran piutang usaha PT. Sanserita Jaya pada tahun 2017 sebesar 3,21 dengan rata-rata pengumpulan piutang 112 hari, pada tahun 2018 tingkat perputaran piutang usaha sebesar 2,26 dengan rata-rata pengumpulan piutang sebesar 159 hari, dan pada tahun 2019 tingkat perputaran piutang usaha sebesar 2,60 dengan rata-rata pengumpulan piutang 139 hari. Idealnya untuk tingkat perputaran piutang usaha adalah 6 kali dalam setahun atau 60 hari paling lambat piutang usaha terbayarkan. Dari tabel diatas menggambarkan tingkat perputaran piutang usaha pada tahun 2017 cukup baik daripada tahun 2018 dan 2019, namun tingkat perputaran 3,21 atau 112 hari menandakan arus kas masuk dari hasil piutang usaha yang 
terbayarkan dari penjualan kredit sangat lama, hal ini mengindikasikan peran dan fungsi bagian piutang usaha kurang efektif dan efisien dalam melakukan tugas dan tanggungjawabnya.

\section{Saran}

PT. Sanserita Jaya hendaknya lebih intensif dalam melakukan pengawasan terhadap fungsi-fungsi setiap bagian, tidak terkecuali untuk bagian piutang usaha. Dan lebih ketat dalam mengawasi setiap prosedur yang telah ditetapkan oleh perusahaan agar setiap bagian divisi melakukan tugas dan tanggung jawabnya dengan baik. Menindaklanjuti penerapan audit operasional sebaiknya pihak manajemen PT. Sanserita Jaya memperhatikan rekomendasi yang diberikan auditor untuk ditindaklanjuti sehingga kinerja bagian piutang usaha dapat ditingkatkan lagi agar lebih efisien, efektif dan ekonomis.

\section{DAFTAR PUSTAKA}

Agoes, S. (2012). Bunga Rampai Auditing (Edisi 2). Jakarta : Salemba Empat.

Alvin Arens, R.J. (2012). Auditing and assurance services : an integrated approach (14th ed.). Jakarta : Salemba Empat.

Bhayangkara, IBK. (2015). Audit Manajemen Prosedur dan Implementasi. Jakarta : Salemba Empat.

Bela, Nofena Eka., Yudhanta Sambharakreshna. (2016). Peranan Audit Operasional Terhadap Kegiatan Penjualan. Jurnal Penelitian Teori \& Terapan Akuntansi,Vol 1(1): 73-82.

Carls, Warren, M.James Reeve \& Philips E. Fees. (2015). Accounting Indonesia Adaptation. Jakarta : Salemba Empat.

Duru, A. Nwakaego, Michael Chidiebere Ekwe, I. Ikechukwu Okpe. (2014). Accounts Receivable Management And Corporate Performance Of Companies In The Food \& Beverage Industry: Evidence From Nigeria. European Journal of Accounting Auditing and Finance Research. Vol. 2(10) : 34-47.

Gade, Muhammad. (2010). Teori Akuntansi. Edisi Pertama. Jakarta : Almahira.

Kieso, D.E, J.J. Weygandt, dan T.D Warfield. (2011). Intermediate Accounting Volume I IFRS Edition. United States of America : Wiley.

Lastianti, S. Desi., Endang Muryani, Mahrus Ali. (2018). The Role of The Internal Audit Management of Enterprise Risk Management. International Journal of Entrepreneurship and Business Development (IJEBD). Vol.1(2) : 110-119.

Mbula, K. Jennifer, Memba, Njeru. A. (2016). Effect of Accounts Receivable on Financial Performance of Firms Funded By Government Venture Capital in Kenya. IOSR Journal of Economics and Finance (IOSR-JEF). Vol.1(1) : 62-69.

Mulyadi. (2014). Auditing. Edisi Keenam. Jakarta : Salemba Empat.

Nazir, M. (2013). Metode Penelitian. Jakarta : Ghalia Indonesia.

Satsangkaryon., Holilah Meliyani. (2015). Peranan Audit Operasional Atas Piutang Usaha Dalam Rangka Meminimalkan Piutang Tak Tertagih Pada PT. Binakarsa Swadaya. Jurnal Ilmiah Akuntansi Fakultas Ekonomi (JIAFE). Vol.1(1):15-19.

Shi, Yanping., Chengke Zhu, Ting Yang. (2016). Determinants of Accounts Receivable: Evidence from Equipment Manufacturing Industry in China. Global Journal of Contemporary Research in Accounting, Auditing and Business Ethics (GJCRA) An Online International Research Journal. Vol. 2(1) : 470-476.

Tahumang, Sulasry.,Ventje Ilat, Treesje Runtu. (2017). Analisis Sistem Pengendalian Internal Piutang Usaha Pada PT. Hasrat Abadi Toyota Cabang Manado. Jurnal Riset Akuntansi Going Concern, Vol 12(2) : 241-250.

Tebety, A. Sanzana, Moch. Dzulkirom, Dwi Atmanto. (2013). Penerapan Audit Operasional Untuk Menilai Efisiensi, Efektivitas, Dan Ekonomisasi Bagian Produksi (Studi Pada PG. Meritjan (Persero) Kediri). Jurnal Administrasi Bisnis Brawijaya, Vol 3(2).

Turetken, Oktay., Stevens Jethefer, Baris Ozkan. (2019). Internal Audit Effectiveness : Operationalization And Influencing Factors. Managerial Auditing Journal., Vol.35(2) : 238-271. 